\title{
Anmeldelse: Sikkerheden i Østersøen
}

Ann-Sofie Dahl står bag en meget nyttig og savnet bog om udviklingen i den sikkerhedspolitiske situation i Østersøregionen. Hun har samlet et kollektiv af forfattere, der kigger på udviklingen fra deres lande eller organisationer. Desværre mangler der et russisk indlæg.

\section{Ann-Sofie Dahl (red.): Strategic} Challenges in the Baltic Sea Region, Georgetown University Press 2018.

I et kort forord skriver tidligere NATO-generalsekretær Anders Fogh Rasmussen, at det er fuldstændig naturligt, at Rusland har interesser i regionen. De skal bare følge de internationale regler, og det har de ikke gjort siden annekteringen af Krim og krigen i Østukraine. På samme måde har Rusland udvist en aggressiv adfærd i Østersøregionen og deployeret iskander-missiler i Kaliningrad.

Fogh Rasmussen mener, at vi må tilbage til normalisering med Rusland, men det kommer vi ikke via splittelse og svaghed. Han synes, NATO har været langsom i sit svar, men mener, at organisationen er ved at have afskrækkelsen på plads; og så er der spørgsmålet om den politiske beredvillighed til at bruge artikel 5. Han kalder bogen et oplæg til debat, men bogen er i virkeligheden mere en lærebog end en debatbog.

Ann-Sofie Dahl introducerer sin bog ved at påvise de fundamentale ændringer, der er sket siden den russiske aggression i 2014, og som satte Østersøen tilbage på NATOs strategiske dags-

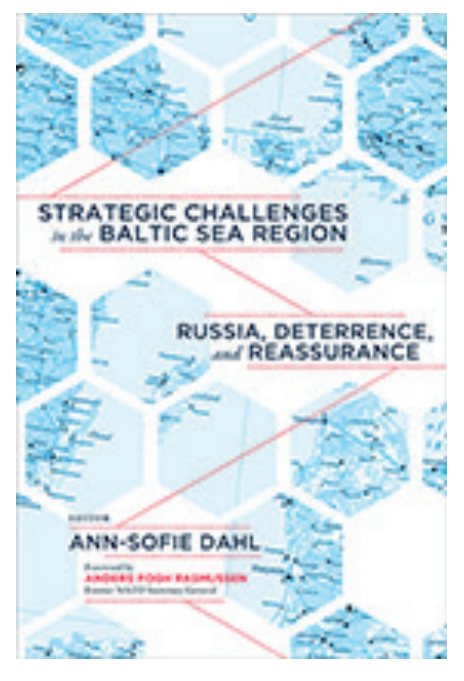

Per Carlsen er fhv. ambassadør, nu seniorrådgiver i Det Udenrigspolitiske Selskab. 
orden på et tidspunkt, hvor alliancen havde rigeligt med andre problemer så som ISIS, flygtningekrise, Syrien og Nordafrika.

Bekymringerne blev kun styrket af udsigten til en potentiel tilnærmelse mellem USA og Rusland, især hvis den blev knyttet til en ny amerikansk holdning til NATOs sikkerhedsgaranti. Hertil kommer den russiske brug af 'hybrid krigsførelse' med cyberteknologi, der gør det svært for allierede at vide hvornår, der er tale om angreb, som kræver et artikel 5-svar. I tillæg til den kendsgerning at Sverige og Finland kun er NATO-partnere og ikke fulde medlemmer.

Professor Robert J. Lieber fra Georgetown Universitetet argumenterer for, at USA stadig er den afgørende magt i regionen og mener, det er for tidligt at afskrive NATO. Præsident Trumps politik ses mere som en mulig fortsættelse af amerikansk engagement end forgængerens trækken sig herfra. Men Lieber er ikke overbevisende, og man kan spørge sig, om han har overbevist sig selv.

\section{Vestens reaktion}

Gudrun Persson fra Stockholms Universitet gennemgår $i$ et glimrende kapitel udviklingen i Ruslands politik og Vestens langsomme reaktion. Hun mener, at Vesten blev overrasket over Ruslands evne til at kombinere militære og ikke militære midler og specielt over den officielle retorik om brug af kernevåben og det forøgede antal øvelser med brug af både strategiske og taktiske a-våben.

Informationskampen fremhæves og Ruslands historiesyn med læng- sel efter Jalta-aftalen, der deler Verden i indflydelsessfærer og ikke giver megen uafhængighed for små stater. Hun gennemgår den russiske nationale sikkerhedsstrategi, brugen af 'soft power', kontrolleret kaos og farvede revolutioner.

Putins omtale af behovet for at korrigere 'fejl i historien' har naturligt nok ført til forøgede bekymringer i de baltiske lande, der kun forstærkes af Ruslands erklærede ret til at tage sig af russeres interesser i udlandet. Hun konkluderer, at Vesten hellere må anerkende den nuværende udfordring og udarbejde en langsigtet respons.

I det efterfølgende kapitel leverer NATOs vicegeneralsekretær Jamie Shea sit svar på den udfordring ved i et kompakt og præcist kapitel at gennemgå, hvordan den vestlige alliance har reageret. Ved NATO-topmødet i Wales blev en Readiness Action Plan vedtaget, der blev implementeret frem til topmødet i Warszawa i 2016 med oprettelsen af en NATO Response Force på 40.000 mand til støtte for den lille Very High Readiness Joint Task Force, der allerede er stationeret i de tre baltiske lande og Polen.

Han gentager, at NATO overholder de indgåede aftaler med Rusland fra 1997 om ikke at stationere substantielle styrker, massiv infrastruktur eller kernevåben på trods af Ruslands konflikt med de internationale retsregler. Han nævner ærligt, at der stadig er arbejde at gøre vedrørende air defence, air space control og sea access til de baltiske lande, når man sammenligner med de 440.000 soldater, der er placeret $i$ Ruslands vestlige militærdistrikt, og de 
store militæreøvelser som Zapad i Belarus i 2017.

Han nævner også, at NATO har taget cyber defence alvorligt. Og samtidig med kampen mod hybridkrig søger man at fremme crisis management, medens man også må søge større militær transparens, confidence building og dermed stabilitet i regionen.

Professor Christopher Coker fra London School of Economics følger op med et kapitel om Vesten og Rusland i en lidt bredere kontekst. Han gengiver kendte synspunkter, som at vi skulle have vidst, hvad der ville ske længe før Krim-annektionen. Han beklager Vestens nedskæringer på forsvarsbevillingerne og siger, at NATO ikke kan forsvare Letland, hvis Rusland skulle vælge at angribe det. Han berører også problemerne med hybrid krigsførelse og artikel 5 og er ikke synderlig optimistisk.

\section{Baltikum}

Tidligere direktør ved det estiske udenrigspolitiske institut, Andres Kasekamp, skriver et meget sympatisk kapitel om de tre baltiske lande og om, hvorfor de ikke er de næste på præsident Putins aggressionsliste. Han hævder, at de baltiske lande i modsætning til Ukraine er velregerede lande med større gennemsigtighed og lavere korruption.

Ligeledes mener han - med rette at Ukraine som slavisk land er noget særligt for Rusland, medens de baltiske lande regnes for noget andet, hvor udviklingen ikke har samme betydning for Rusland. Han ser det største problem i Ruslands krav om at beskytte russiske statsborgere i udlandet, men mener omvendt ikke, at de russiske mindretal i de baltiske lande har noget ønske om at 'vende hjem'.

Han konstaterer, at Rusland i følge RAND-studier ville kunne indtage Tallinn eller Riga på 60 timer, men mener, at balterne har lært at leve med bjørnen og lært, at svaghed inviterer til aggression. Man har derfor truffet de nødvendige forholdsregler så som genindførelsen af værnepligten; men der er stadig problemer med de russiske medier, som søges udnyttet af bevægelsen 'russkij mir,' hvorved der opstår to separate informationskamre, hvilket er søgt imødegået ved oprettelse af en ny selvstændig russisk tv-kanal.

Mikkel Vedby Rasmussen vælger en utraditionel tilgang til begrebet A2/AD (Anti Access/Area Denial) og sammenligner med Danmarks krig med Storbritannien 1807-1814. Det er faktisk en glimrende forklaring, også til at forstå det strategiske mål for Vesten, nemlig at gøre Østersøen til 'forgiftet sø'. Til sidst sender Vedby kavaleriet til undsætning for at nå Vilnius før russerne. Et umådeligt veloplagt og velskrevet kapitel.

Det svageste kapitel skrives af Justyna Gotkowska, fra Center for Øst-Studier i Warszawa. Hun gentager, hvad der er allerede beskrevet om den russiske trussel og NATOs svar, og berører kun meget kort den polske vinkel og etableringen af hovedkvarteret i Szczecin og Polens forslag på Warszawa-topmødet. Lidt ærgerligt, for vi har behov for at forstå tænkningen hos vor store nabo i sydøst. 


\section{Tysklands rolle}

Til gengæld skriver de to tyskere Claudia Major og Alicia von Voss kort og klart om Tysklands rolle i regionen. De oplyser, at Tyskland i stadig højere grad deltager i styrkelsen af den regionale sikkerhed, medens man tidligere ikke interesserede sig meget i Berlin for den nordlige region og lagde vægten på at være forligsmand mellem øst og vest med lige vægt på deterrence og detente.

$\mathrm{Nu}$ er Tyskland imidlertid den største europæiske troppebidragsyder til 'reassurancemeasures' i Øst. Der har imidlertid været rapporter om tysk personels manglende træning og udstyrets standard, men det er nu under udbedring. Tyskland ønsker dog ikke at forværre forholdet til Rusland yderligere, hvorfor man lægger vægten på præventive forholdsregler, civile instrumenter og medie og kommunikation for at imødegå russisk propaganda.

\section{Norge, Sverige og Finland}

Håkon Lunde Saxi, norsk forsvarsforsker, beskriver klart, at Norges interesser traditionelt har ligget $\mathrm{i}$ nord - ikke i Østersøen. Man ønskede Rusland som partner og var derfor i begyndelsen også skeptisk over for NATO-udvidelsen. Man støttede de danske og svenske initiativer i Østersøen, med uden entusiasme og prioritering. Dette ændredes imidlertid med Ukraine-krisen. Man lægger vægten på artikel 5, og da der er roligt i nord, er man gået mere aktivt ind i Østersøen for at støtte den vestlige sikkerhedsorden og afskrækkelse.
I det sidste afsnit beskæftiger bogen sig med Finlands og Sveriges rolle. Forsvarsrådgiver Johan Raeder beskæftiger sig med Gotlands specifikke betydning. Han beskriver de militære nedskæringer efter den kolde krig i Sverige og især på Gotland. Efter Georgien-krigen i 2008, Krim-annekteringen og Ukraine-krigen besluttede Sverige igen at styrke forsvaret generelt og især på Gotland, hvilket vil gøre det vanskeligt i en konfliktsituation for Rusland at forhindre vestlige basefaciliteter på øen.

Ann-Sofie Dahl gennemgår i et udmærket kapitel Sveriges og Norges forhold til NATO som tætte partnere - ikke medlemmer. Hun omtaler the Enhanced Opportunities Partnership (EOP) som et guldkortarrangement så tæt på medlemskab, som man kan komme. Man har dertil styrket sit eget forsvar og indgået aftaler med hinanden, med de nordiske lande, med Danmark og Polen, med Storbritannien og især USA. Medlemskab af NATO diskuteres, men er stadig ikke nært forestående. Hun fastslår afsluttende, at der stadig er forskel på en partner og en allieret.

Til slut gennemgår Karoliina Honkanen Finlands fornyede fokus på kollektiv sikkerhed. Det indeholder en række gentagelser fra det foregående kapitel og kunne med fordel have været redigeret strammere. 